Article

\title{
Cytotoxic and Radical Scavenging Nor-Dammarane Triterpenoids from Viburnum mongolicum
}

\author{
Xiaohua Wang ${ }^{1}$ and Wei Wang ${ }^{2, *}$ \\ 1 Department of Pharmacy, No.202 Hospital of PLA, Shenyang 110003, China \\ 2 Department of Pharmacy, No.455 Hospital of PLA, Shanghai 200052, China \\ * Author to whom correspondence should be addressed; E-Mail: sywwang@sohu.com; \\ Tel./Fax: +86-21-8181-5099.
}

Received: 11 December 2012; in revised form: 28 December 2012 / Accepted: 5 January 2013 / Published: 24 January 2013

\begin{abstract}
The ethanol extract of the whole plants of Viburnum mongolicum afforded six new nor-dammarane triterpenoids: $3 \beta, 12 \beta$-dihydroxy-25,26,27-trinordammara-22-en -24,20-olide (1), 3 $\beta, 12 \beta$-dihydroxy-24 $\alpha$-methoxy-25,26,27-trinordammara-20,24-epoxy

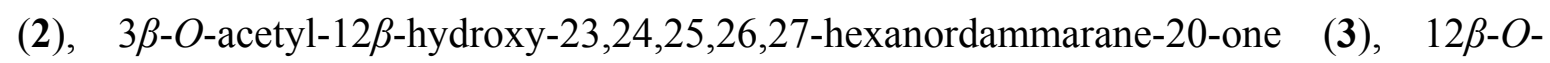
acetyl-15 $\alpha$-hydroxy-17 $\beta$-methoxy-3-oxo-20,21,22-23,24,25,26,27-octanordammanrane (4), $12 \beta$ - $O$-acetyl-15 $\alpha, 17 \beta$-dihydroxy-3-oxo-20,21,22-23,24,25,26,27-octanordammanrane (5), and $12 \beta, 15 \alpha$-dihydroxy-3-oxo-17-en-20,21,22-23,24,25,26,27-octanordammanrane (6), together with two known nor-dammarane triterpenoids, $12 \beta$-hydroxy-3-oxo-24 $\alpha$-methoxy25,26,27-trinordammara-20,24-epoxy (7) and $3 \beta, 12 \beta$-dihydroxy-23,24,25,26,27hexanordammarane-20-one (8). The structures of the isolated compounds were established based on 1D and 2D $\left({ }^{1} \mathrm{H}-{ }^{1} \mathrm{H}\right.$ COSY, HMQC, and HMBC) NMR spectroscopy, in addition to high resolution mass spectrometry. The isolated compounds were tested in vitro for cytotoxic potential against seven tumor cell lines and radical scavenging activities. Compounds 4-6 exhibited significant cytotoxic activities against all tested tumor cell lines and radical scavenging activities against $\mathrm{ABTS}^{+}$radicals comparable with the standard drug Trolox.
\end{abstract}

Keywords: Viburnum mongolicum; Caprifliaceae; nor-dammarane triterpenoids; cytotoxicity; radical scavenging activities 


\section{Introduction}

The genus Viburnum, which belongs to the family of Caprifliaceae, comprises more than 230 species [1,2]. The majority of them are endemic and mainly distributed in the temperate or subtropical zones, particularly from South America (Peru) to South-East Asia (Philippines and Malaysia) [3,4]. Among them, 80 species naturally occur in China [5]. Viburnum species have diuretic, antispasmodic and sedative properties, mainly for uterine excitability and are commonly used as a traditional Chinese herbal medicine as an astringent, sedative, emmengagogue and the treatment of other health problems [6,7]. The genus Viburnum is known to be rich in iridoids, iridoid glycosides, sesquiterpenes, vibsane diterpenes, triterpenes, triterpene saponins, flavonoids, lignans, coumarins, and caffeoyl acid derivatives [8-24]. As part of our search for novel and bioactive constituents, Viburnum mongolicum (Pall.) Rehd., an evergreen shrub, has been investigated. It is widely distributed in the Menggu, Hebei, Shanxi, Ningxia, Gansu and Qinghai provinces of China. A literature search revealed that phytochemical and pharmacological studies have rarely been undertaken within this species [5]. As part of our search for novel and bioactive constituents, a phytochemical study of the chloroform-soluble fraction of the $80 \% \mathrm{EtOH}$ extract of $V$. mongolicum was undertaken, which

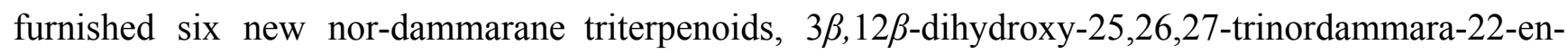

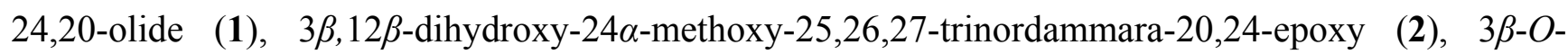
acetyl-12 $\beta$-hydroxy-23,24,25,26,27-hexanordammarane-20-one (3), 12 $\beta$-O-acetyl-15 $\alpha$-hydoxy-17 $\beta$ methoxy-3-oxo-20,21,22-23,24,25,26,27-octanordammanrane (4), 12 $\beta$-O-acetyl-15 $\alpha, 17 \beta$-dihydoxy-3oxo-20,21,22-23,24,25,26,27-octanordammanrane (5), and 12 $\beta, 15 \alpha$-dihydoxy-3-oxo-17-en-20,21,2223,24,25,26,27-octanordammanrane (6), and two known compounds, 12 $\beta$-hydroxy-3-oxo- $24 \alpha$ methoxy-25,26,27-trinordammara-20,24-epoxy (7) and 3 $\beta, 12 \beta$-dihydroxy-23,24,25,26,27-hexanordammarane-20-one (8) (Figure 1). The six new compounds are endowed with three different triterpenoid skeletons: $\mathbf{1}$ and $\mathbf{2}$ are trinordammaranes, $\mathbf{3}$ is a hexanordammarane, and $\mathbf{4 - 6}$ are octanordammaranes. This paper describes the isolation and structure elucidation of the new compounds, as well as the tested in vitro cytotoxic and radical scavenging activities of compounds $\mathbf{1}-\mathbf{8}$.

Figure 1. Structures of compounds 1-8.

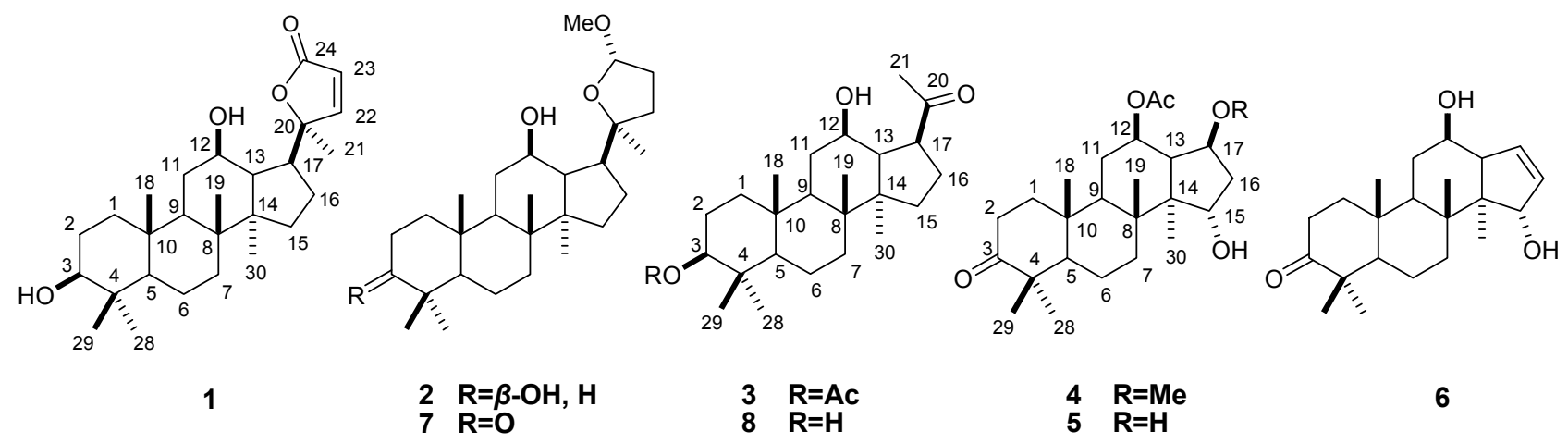




\section{Results and Discussion}

\subsection{Chemistry}

Compound 1 was obtained as a white amorphous powder. Its positive HR-ESI-MS spectrum showed a quasimolecular ion peak at $\mathrm{m} / z 453.2984[\mathrm{M}+\mathrm{Na}]^{+}$, consistent with the molecular formula $\mathrm{C}_{27} \mathrm{H}_{42} \mathrm{O}_{4}$ (calcd. for $\mathrm{C}_{27} \mathrm{H}_{42} \mathrm{O}_{4} \mathrm{Na} 453.2981$ ), accounting for seven degrees of unsaturation. The IR spectrum indicated the presence of $\mathrm{OH}\left(3450 \mathrm{~cm}^{-1}\right)$ and $\mathrm{C}=\mathrm{O}\left(1702 \mathrm{~cm}^{-1}\right)$ groups, as well as a $\mathrm{C}=\mathrm{C}$ bond $\left(1640 \mathrm{~cm}^{-1}\right)$. ${ }^{1} \mathrm{H}-\mathrm{NMR}$ signals for six methyl groups $\left[\delta_{\mathrm{H}} 1.45,0.99,0.91,0.89,0.84\right.$ and 0.79 (each, s)] and for two oxygenated $\mathrm{CH}$ groups $\left[\delta_{\mathrm{H}} 3.21(\mathrm{H}-3)\right.$ and $\left.3.62(\mathrm{H}-12)\right]$ were observed (Table 1). The characteristic ${ }^{13} \mathrm{C}-\mathrm{NMR}$ spectrum, which was similar to that of the known compound cylindrictone $\mathrm{B}$ [25], indicated the 27 skeleton carbons in $\mathbf{1}$ as composed of six methyls, seven methylenes, eight methines (two oxygenated and two olefinic), five quaternary carbons and one $\mathrm{C}=\mathrm{O}$ group $\left(\delta_{\mathrm{C}} 172.1\right)$. The distinct difference was that the ketone carbon signal at C-3 in cylindrictone $\mathrm{B}$ was replaced by an oxygenated methine $\left(\delta_{\mathrm{H}} 3.21 ; \delta_{\mathrm{C}} 78.5\right)$ in 1 , which was supported by the observation of a $\mathrm{CH}_{2}-\mathrm{CH}_{2}-\mathrm{CH}-\mathrm{O}$ spin system in the ${ }^{1} \mathrm{H},{ }^{1} \mathrm{H}-\mathrm{COSY}$ spectrum and the HMBC correlations between $\mathrm{C}-3\left(\delta_{\mathrm{C}} 78.5\right)$ with $\mathrm{H}-1$ $\left(\delta_{\mathrm{H}} 1.03\right.$ and 1.69$), \mathrm{H}-5\left(\delta_{\mathrm{H}} 0.78\right), \mathrm{H}-28\left(\delta_{\mathrm{H}} 0.79\right)$ and $\mathrm{H}-29\left(\delta_{\mathrm{H}} 0.99\right)$ (Figure 2$)$. Analysis of the HMBC spectrum of 1 assigned the $\mathrm{OH}$ group to $\mathrm{C}-12$ due to the long-range correlations of $\mathrm{H}-9$ and $\mathrm{H}-17$ to $\mathrm{C}-12$, and of $\mathrm{H}-12$ to $\mathrm{C}-14$. The $\mathrm{C}=\mathrm{C}$ bond was located between $\mathrm{C}-22$ and $\mathrm{C}-23$ because of the presence of HMBC correlations from $\mathrm{H}-22$ and $\mathrm{H}-23$ to $\mathrm{C}-24$ and $\mathrm{C}-20$ respectively. The relative configuration of 1 was established through an analysis of the ROESY data. The $\beta$-orientation of the $3-$ and $12-\mathrm{OH}$ was deduced from the correlations of $\mathrm{H}-3$ with $\mathrm{H}-1 \mathrm{ax}$ and $\mathrm{H}-5$, and of $\mathrm{H}-12$ with $\mathrm{H}-9$ and $\mathrm{H}-30$. The presence of ROESY correlations of H-21 with H-17 and H-12 verified the $\alpha$-orientation of Me at C-21. Thus, 1 was identified as 3 $\beta, 12 \beta$-dihydroxy-25,26,27-trinordammara-22-en-24,20-olide.

Compound 2 was obtained as a white amorphous powder. Its positive HR-ESI-MS spectrum showed a quasimolecular ion peak at $\mathrm{m} / z 471.3454[\mathrm{M}+\mathrm{Na}]^{+}$, consistent with the molecular formula $\mathrm{C}_{28} \mathrm{H}_{48} \mathrm{O}_{4}$ (calcd. for $\mathrm{C}_{28} \mathrm{H}_{48} \mathrm{O}_{4} \mathrm{Na}$ 471.3450), accounting for five degrees of unsaturation. The IR spectrum absorptions at $3425 \mathrm{~cm}^{-1}$ indicated the presence of the $\mathrm{OH}$ group. The ${ }^{1} \mathrm{H}-\mathrm{NMR}$ spectrum (Table 1) and ${ }^{13} \mathrm{C}-\mathrm{NMR}$ data (Table 2), along with the DEPT and HSQC experiments, showed that the carbons were seven methyls (including one methoxy group), nine methylenes, seven methines (including three oxygenated methine groups), and five quaternary $\mathrm{C}$-atoms (including one oxygenated $\mathrm{C}$-atom). These NMR data were quite similar to those of $12 \beta$-hydroxy-3-oxo-24 $\alpha$-methoxy-25,26,27trinordammara-20,24-epoxy (7), except for the replacement of the ketone carbonyl of C-3 by a hydroxymethylene moiety $\left(\delta_{\mathrm{H}} 3.17 ; \delta_{\mathrm{C}} 78.4\right)$. This was supported by HMBC correlations from the $\mathrm{H}-3$ to C-1 $\left(\delta_{\mathrm{C}} 38.8\right), \mathrm{C}-5\left(\delta_{\mathrm{C}} 56.0\right), \mathrm{C}-28\left(\delta_{\mathrm{C}} 15.2\right)$, and C-29 $\left(\delta_{\mathrm{C}} 27.9\right)$. These HMBC correlations of the oxygenated H-24 $\left(\delta_{\mathrm{H}} 4.93\right)$ with the oxygenated quaternary C-atom C-20 ( $\left.\delta_{\mathrm{C}} 80.4\right)$ and methoxy $\left(\delta_{\mathrm{C}} 55.4\right)$ suggested that $\mathrm{C}-20$ and $\mathrm{H}-24$ were linked via $\mathrm{O}$ bridge to form a lactol ring, and the methoxy group was placed at C-24. The relative configuration of $\mathbf{2}$ was confirmed by a ROESY experiment. In the ROESY spectrum, the correlations of $\mathrm{H}-3 / \mathrm{H}-1 \mathrm{ax}$ and $\mathrm{H}-5$ indicated that the $\mathrm{OH}-3$ was $\beta$-oriented. The $\alpha$-orientation of the methoxy group at C-24 was determined to be identical to that of 7 on the basis of ROESY correlation of H-24 with Hax-22 and of H-21 with Heq-22. Thus, the structure of 2 was established as $3 \beta, 12 \beta$-dihydroxy-24 $\alpha$-methoxy-25,26,27-trinordammara-20,24-epoxy. 
Table 1. ${ }^{1} \mathrm{H}-\mathrm{NMR}$ data of compounds $\mathbf{1}-\mathbf{6}$ in $\mathrm{CDCl}_{3}(\delta$ in ppm and $J$ in $\mathrm{Hz})$.

\begin{tabular}{|c|c|c|c|c|c|c|}
\hline No. & 1 & 2 & 3 & 4 & 5 & 6 \\
\hline $1 \mathrm{ax}$ & $\begin{array}{c}1.03(d d d, 13.8 \\
13.3,3.6)\end{array}$ & $\begin{array}{c}1.00(d d d, 14.0 \\
13.5,3.6)\end{array}$ & $\begin{array}{c}1.02(d d d, 14.0 \\
13.2,3.6)\end{array}$ & $\begin{array}{c}1.47(d d d, 14.0 \\
13.3,3.6)\end{array}$ & $\begin{array}{c}1.44(d d d, 13.8 \\
13.6,3.6)\end{array}$ & $\begin{array}{c}1.45(d d d, 13.8 \\
13.6,3.6)\end{array}$ \\
\hline leq & $\begin{array}{c}1.69(d d d, 13.3 \\
4.0,3.6)\end{array}$ & $\begin{array}{c}1.66(d d d, 13.5 \\
4.0,3.6)\end{array}$ & $\begin{array}{c}1.68(d d d, 13.2 \\
4.0,3.6)\end{array}$ & $\begin{array}{c}1.95(d d d, 13.3 \\
4.0,3.6)\end{array}$ & $\begin{array}{c}1.94(d d d, 13.3 \\
4.0,3.6)\end{array}$ & $\begin{array}{c}1.93(d d d, \\
13.5,3.8,3.6)\end{array}$ \\
\hline $2 a x$ & $1.59(\mathrm{~m})$ & $1.56(m)$ & $1.59(m)$ & $\begin{array}{c}2.38(d d d, 14.0 \\
13.3,3.6)\end{array}$ & $\begin{array}{c}2.36(d d d, 13.8 \\
13.6,3.6)\end{array}$ & $\begin{array}{c}2.39(d d d, 13.8 \\
13.6,3.6)\end{array}$ \\
\hline $2 \mathrm{eq}$ & $1.67(m)$ & $1.64(m)$ & $1.66(m)$ & $\begin{array}{c}2.52(d d d, 13.3 \\
4.0,3.6)\end{array}$ & $\begin{array}{c}2.48(d d d, 13.3 \\
4.0,3.6)\end{array}$ & $\begin{array}{c}2.47(d d d, 13.5 \\
3.8,3.6)\end{array}$ \\
\hline 3 & $\begin{array}{c}3.21(d d, 14.0 \\
4.0)\end{array}$ & $\begin{array}{c}3.17(d d, 14.0, \\
4.0)\end{array}$ & $\begin{array}{c}4.39(d d, 14.0, \\
4.0)\end{array}$ & - & - & - \\
\hline 5 & $\begin{array}{c}0.78(d d, 14.0 \\
3.8)\end{array}$ & $\begin{array}{c}0.76(d d, 13.8 \\
3.8)\end{array}$ & $\begin{array}{c}0.79(d d, 13.8 \\
3.6)\end{array}$ & $\begin{array}{c}1.37(d d, 13.8 \\
3.8)\end{array}$ & $\begin{array}{c}1.35(d d, 13.5 \\
3.0)\end{array}$ & $\begin{array}{c}1.36(d d, 13.0 \\
3.0)\end{array}$ \\
\hline $6 a x$ & $1.47(\mathrm{~m})$ & $1.46(\mathrm{~m})$ & $1.48(\mathrm{~m})$ & $1.44(\mathrm{~m})$ & $1.42(\mathrm{~m})$ & $1.48(\mathrm{~m})$ \\
\hline 6 eq & $1.62(\mathrm{~m})$ & $1.58(\mathrm{~m})$ & $1.60(\mathrm{~m})$ & $1.58(\mathrm{~m})$ & $1.56(\mathrm{~m})$ & $1.59(\mathrm{~m})$ \\
\hline $7 \mathrm{ax}$ & $\begin{array}{c}1.58(d d d, 14.0 \\
13.5,3.8)\end{array}$ & $\begin{array}{c}1.55(d d d, 14.0 \\
13.3,3.8)\end{array}$ & $\begin{array}{c}1.57(d d d, 14.0 \\
13.5,3.8)\end{array}$ & $\begin{array}{c}1.54(d d d, 13.8 \\
13.3,3.8)\end{array}$ & $1.53(m)$ & $1.54(\mathrm{~m})$ \\
\hline 7 eq & $\begin{array}{c}2.18(d d d, 13.5 \\
4.0,3.6)\end{array}$ & $\begin{array}{c}2.15(d d d, 13.3 \\
4.0,3.6)\end{array}$ & $\begin{array}{c}2.17(d d d, 13.5 \\
4.0,3.6)\end{array}$ & $2.20(\mathrm{~m})$ & $2.18(m)$ & $2.19(m)$ \\
\hline 9 & $\begin{array}{c}1.55(d d, 13.6 \\
3.0)\end{array}$ & $\begin{array}{c}1.53(d d, 13.6, \\
3.2)\end{array}$ & $\begin{array}{c}1.55(d d, 13.6, \\
3.2)\end{array}$ & $\begin{array}{c}1.51(d d, 13.0 \\
3.0)\end{array}$ & $\begin{array}{c}1.49(d d, 13.8 \\
3.0)\end{array}$ & $\begin{array}{c}1.52(d d, 13.5 \\
3.0)\end{array}$ \\
\hline $11 \mathrm{ax}$ & $1.27(\mathrm{~m})$ & $1.26(\mathrm{~m})$ & $1.27(\mathrm{~m})$ & $1.27(\mathrm{~m})$ & $1.26(\mathrm{~m})$ & $1.24(\mathrm{~m})$ \\
\hline $11 \mathrm{eq}$ & $1.84(\mathrm{~m})$ & $1.87(\mathrm{~m})$ & $1.89(\mathrm{~m})$ & $1.92(\mathrm{~m})$ & $1.91(\mathrm{~m})$ & $1.84(\mathrm{~m})$ \\
\hline 12 & $3.62(\mathrm{~m})$ & $3.47(\mathrm{~m})$ & $3.49(\mathrm{~m})$ & $4.47(m)$ & $4.44(m)$ & $3.80(\mathrm{~m})$ \\
\hline 13 & $\begin{array}{c}1.44(d d, 13.8 \\
3.2)\end{array}$ & $\begin{array}{c}2.16(d d, 13.8, \\
3.2)\end{array}$ & $\begin{array}{c}2.08(d d, 13.8, \\
3.2)\end{array}$ & $\begin{array}{c}2.12(d d, 13.0, \\
3.0)\end{array}$ & $\begin{array}{c}2.11(d d, 13.6 \\
3.0)\end{array}$ & $\begin{array}{c}2.78(d d, 13.6 \\
8.0)\end{array}$ \\
\hline $15 \mathrm{ax}$ & $\begin{array}{c}1.17(d d d, 13.8 \\
13.0,3.6)\end{array}$ & $\begin{array}{c}1.76(d d d, 13.8 \\
13.2,3.6)\end{array}$ & $\begin{array}{c}1.21(d d d, 13.8 \\
13.3,3.6)\end{array}$ & $\begin{array}{c}3.48(d d, 13.0, \\
3.0)\end{array}$ & $\begin{array}{c}3.44(d d, 13.6 \\
3.0)\end{array}$ & $4.55(d, 7.6)$ \\
\hline $15 \mathrm{eq}$ & $\begin{array}{c}1.56(d d d, 13.0 \\
4.0,3.6)\end{array}$ & $\begin{array}{c}1.77(d d d, 13.2 \\
4.0,3.6)\end{array}$ & $\begin{array}{c}1.68(d d d, 13.2 \\
4.0,3.6)\end{array}$ & - & - & - \\
\hline $16 a x$ & $1.80(m)$ & $1.70(\mathrm{~m})$ & $1.72(\mathrm{~m})$ & $2.02(m)$ & $1.98(m)$ & $\begin{array}{c}5.63(d d, 10.8 \\
7.6)\end{array}$ \\
\hline $16 \mathrm{eq}$ & $2.05(\mathrm{~m})$ & $2.02(\mathrm{~m})$ & $2.04(\mathrm{~m})$ & $2.35(\mathrm{~m})$ & $2.32(\mathrm{~m})$ & - \\
\hline 17 & $2.29(m)$ & $2.22(\mathrm{~m})$ & $2.88(m)$ & $3.98(m)$ & $4.23(m)$ & $\begin{array}{c}6.62(d d, 10.8 \\
8.0)\end{array}$ \\
\hline 18 & $0.91(s)$ & $0.96(s)$ & $1.06(s)$ & $0.87(s)$ & $0.85(s)$ & $0.89(s)$ \\
\hline 19 & $0.89(s)$ & $0.93(s)$ & $0.99(s)$ & $0.99(s)$ & $0.96(s)$ & $0.98(s)$ \\
\hline 21 & $1.45(\mathrm{~s})$ & $1.35(\mathrm{~s})$ & $2.24(\mathrm{~s})$ & - & - & - \\
\hline $22 \mathrm{ax}$ & $7.86(d, 5.7)$ & $1.84(\mathrm{~m})$ & - & - & - & - \\
\hline $22 \mathrm{eq}$ & - & $1.95(\mathrm{~m})$ & - & - & - & - \\
\hline $23 a x$ & $6.06(d, 5.7)$ & $1.98(\mathrm{~m})$ & - & - & - & - \\
\hline $23 \mathrm{eq}$ & - & $2.05(\mathrm{~m})$ & - & - & - & - \\
\hline 24 & - & $4.93(\mathrm{~m})$ & - & - & - & - \\
\hline 28 & $0.79(s)$ & $0.77(s)$ & $0.78(s)$ & $0.79(s)$ & $0.77(s)$ & $0.78(s)$ \\
\hline 29 & $0.99(s)$ & $0.97(s)$ & $0.98(s)$ & $1.01(\mathrm{~s})$ & $0.98(s)$ & $1.03(s)$ \\
\hline 30 & $0.84(s)$ & $0.89(s)$ & $0.91(s)$ & $1.24(s)$ & $1.19(s)$ & $1.26(\mathrm{~s})$ \\
\hline$M \mathrm{e}$ & - & - & $2.01(\mathrm{~s})$ & $2.10(s)$ & $2.08(s)$ & - \\
\hline $\mathrm{OMe}$ & - & $3.26(s)$ & - & $3.21(\mathrm{~s})$ & - & - \\
\hline
\end{tabular}


Table 2. ${ }^{13} \mathrm{C}-\mathrm{NMR}$ data of compounds $\mathbf{1}-\mathbf{6}$ in $\mathrm{CDCl}_{3}$.

\begin{tabular}{|c|c|c|c|c|c|c|}
\hline No. & 1 & 2 & 3 & 4 & 5 & 6 \\
\hline 1 & $38.8(t)$ & $38.8(t)$ & $39.0(t)$ & $40.1(t)$ & $39.6(t)$ & $39.6(t)$ \\
\hline 2 & $27.1(t)$ & $27.1(t)$ & $27.2(t)$ & $34.2(t)$ & $33.9(t)$ & $33.8(t)$ \\
\hline 3 & $78.5(d)$ & $78.4(d)$ & $81.3(d)$ & $218.8(s)$ & $218.7(s)$ & $219.2(s)$ \\
\hline 4 & $38.9(s)$ & $38.8(s)$ & $38.9(s)$ & $47.6(s)$ & $47.2(s)$ & $47.7(s)$ \\
\hline 5 & $55.6(d)$ & $56.0(d)$ & $56.0(d)$ & $55.5(d)$ & $55.2(d)$ & $55.8(d)$ \\
\hline 6 & $17.8(t)$ & $17.9(t)$ & $18.0(t)$ & $19.7(t)$ & $20.2(t)$ & $20.1(t)$ \\
\hline 7 & $32.8(t)$ & $33.4(t)$ & $33.3(t)$ & $34.6(t)$ & $34.5(t)$ & $35.1(t)$ \\
\hline 8 & $39.8(s)$ & $39.0(s)$ & $39.0(s)$ & $39.9(s)$ & $39.8(s)$ & $39.7(s)$ \\
\hline 9 & $50.1(d)$ & $50.8(d)$ & $51.0(d)$ & $50.1(d)$ & $49.9(d)$ & $49.7(d)$ \\
\hline 10 & $37.4(s)$ & $37.7(s)$ & $37.5(s)$ & $37.2(s)$ & $36.7(s)$ & $37.3(s)$ \\
\hline 11 & $32.3(t)$ & $32.7(t)$ & $32.4(t)$ & $32.7(t)$ & $32.1(t)$ & $35.8(t)$ \\
\hline 12 & $70.7(d)$ & $71.9(d)$ & $71.2(d)$ & $73.1(d)$ & $72.9(d)$ & $71.0(d)$ \\
\hline 13 & $49.6(d)$ & $50.9(d)$ & $50.9(d)$ & $47.7(d)$ & $47.4(d)$ & $58.1(d)$ \\
\hline 14 & $51.7(s)$ & $53.3(s)$ & $51.1(s)$ & $55.3(s)$ & $54.8(s)$ & $60.3(s)$ \\
\hline 15 & $31.1(t)$ & $33.2(t)$ & $31.8(t)$ & $69.9(d)$ & $69.4(d)$ & $68.0(d)$ \\
\hline 16 & $26.4(t)$ & $31.1(t)$ & $26.8(t)$ & $39.4(t)$ & $39.0(t)$ & $132.1(d)$ \\
\hline 17 & $47.0(d)$ & $50.7(d)$ & $52.9(d)$ & $76.4(d)$ & $71.5(d)$ & $158.8(d)$ \\
\hline 18 & $14.8(q)$ & $15.6(q)$ & $15.2(q)$ & $16.1(q)$ & $16.2(q)$ & $16.0(q)$ \\
\hline 19 & $15.6(q)$ & $16.7(q)$ & $16.0(q)$ & $18.9(q)$ & $18.8(q)$ & $20.5(q)$ \\
\hline 20 & $91.7(s)$ & $80.4(s)$ & $215.4(s)$ & - & - & - \\
\hline 21 & $22.5(q)$ & $30.5(q)$ & $29.4(q)$ & - & - & - \\
\hline 22 & $161.3(d)$ & $29.2(t)$ & - & - & - & - \\
\hline 23 & $120.5(d)$ & $33.8(t)$ & - & - & - & - \\
\hline 24 & $172.1(s)$ & $107.5(d)$ & - & - & - & - \\
\hline 28 & $15.4(q)$ & $15.2(q)$ & $15.3(q)$ & $16.0(q)$ & $15.9(q)$ & $15.9(q)$ \\
\hline 29 & $28.0(q)$ & $27.9(q)$ & $28.0(q)$ & $28.1(q)$ & $28.0(q)$ & $28.0(q)$ \\
\hline 30 & $17.2(q)$ & $17.9(q)$ & $16.7(q)$ & $16.2(q)$ & $14.9(q)$ & $19.9(q)$ \\
\hline $\mathrm{C}=\mathrm{O}$ & - & - & $172.9(s)$ & $173.1(s)$ & $172.6(s)$ & - \\
\hline $\mathrm{Me}$ & - & - & $21.7(q)$ & $22.1(q)$ & $21.3(q)$ & - \\
\hline $\mathrm{OMe}$ & - & $55.4(q)$ & - & $58.6(q)$ & - & - \\
\hline
\end{tabular}

Compound 3, a white amorphous powder, exhibited a molecular formula of $\mathrm{C}_{26} \mathrm{H}_{42} \mathrm{O}_{4}$, based on the HRESIMS spectrum which showed a pseudomolecular ion at $\mathrm{m} / \mathrm{z} 441.2978[\mathrm{M}+\mathrm{Na}]^{+}$(calcd. 441.2981). The IR absorptions at 3440 and $1705 \mathrm{~cm}^{-1}$ indicated the presence of $\mathrm{OH}$ and $\mathrm{C}=\mathrm{O}$ groups, respectively. Its NMR data were similar to those of $\mathbf{2}$, suggesting that $\mathbf{3}$ possessed a dammarane-type triterpenoid skeleton with the exception of the side chain resonances. The presence of one isolated aceto-group on C-17 was deduced by the HMBC correlation of H-17 $\left(\delta_{\mathrm{H}} 2.88\right)$ with Me-21 $\left(\delta_{\mathrm{C}} 29.4\right)$, and of H-13 $\left(\delta_{\mathrm{H}} 2.08\right)$ and $\mathrm{H}-16\left(\delta_{\mathrm{H}} 1.72\right.$ and 2.04$)$ with the ketone of $\mathrm{C}-20\left(\delta_{\mathrm{C}} 215.4\right)$ (Figure 2$)$. Comparing the NMR data of $\mathbf{3}$ with those of compound $\mathbf{8}$, the significant difference was that one acetyl group on C-3 in 3 took the place of the hydroxy group in $\mathbf{8}$, which was confirmed by HMBC correlations of $\mathrm{H}-3\left(\delta_{\mathrm{H}} 4.39\right)$ with $\mathrm{C}=\mathrm{O}\left(\delta_{\mathrm{C}} 172.9\right)$ of acetyl group and of $\mathrm{C}-3$ with $\mathrm{H}-1, \mathrm{H}-5, \mathrm{H}-28$ and H-29. H-3 and H-12 were found to be $\alpha$-oriented on the basis of ROESY cross-peaks of $\mathrm{H}-3 / \mathrm{H}-1$ ax and $\mathrm{H}-5$, and of $\mathrm{H}-12 / \mathrm{H}-9$ and H-30 (Figure 2). Thus, compound 3 was elucidated as $3 \beta$ - $O$-acetyl-12 $\beta$-hydroxy-23,24,25,26,27hexanordammarane-20-one. 
Figure 2. Key $\mathrm{HMBC}(\frown)$ and ${ }^{1} \mathrm{H}-{ }^{1} \mathrm{H} \operatorname{COSY}(-)$ correlations of compounds $\mathbf{1}, \mathbf{3}$ and 4.

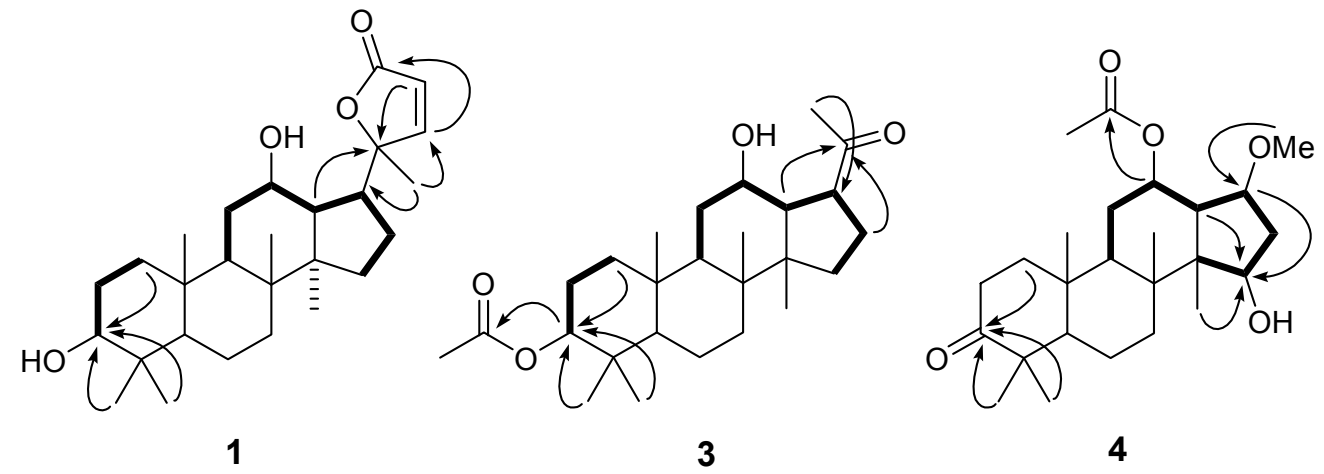

Compound 4 was obtained as a white amorphous solid. The HRESIMS displayed a pseudomolecular ion at $\mathrm{m} / z 443.2774[\mathrm{M}+\mathrm{Na}]^{+}$(calcd. for $\mathrm{C}_{25} \mathrm{H}_{40} \mathrm{O}_{5} \mathrm{Na}, 443.2773$ ) consistent with a molecular formula of $\mathrm{C}_{25} \mathrm{H}_{40} \mathrm{O}_{5}$, corresponding to six degrees of unsaturation. The IR of 4 showed the strong broad absorption of $\mathrm{OH}\left(3450 \mathrm{~cm}^{-1}\right)$ and $\mathrm{C}=\mathrm{O}\left(1735 \mathrm{~cm}^{-1}\right)$. The ${ }^{1} \mathrm{H}-\mathrm{NMR}$ spectrum exhibited the signals of six singlet $\mathrm{Me}$, one $\mathrm{OMe}$, and three oxygenated $\mathrm{CH}\left(\delta_{\mathrm{H}} 3.48,3.98\right.$ and 4.47$)$. The ${ }^{13} \mathrm{C}-\mathrm{NMR}$ and DEPT spectra showed the signals of six quaternary carbons (including one ester, one ketone, and four $\mathrm{sp}^{3} \mathrm{C}$-atoms), six $\mathrm{CH}$, six $\mathrm{CH}_{2}$, six $\mathrm{Me}$, and one $\mathrm{MeO}$ ). The unsaturation degrees (including two $\mathrm{C}=\mathrm{O}$ ) indicated that the skeleton of 4 was the derivative of a four-ring triterpenoid. Based on the NMR data, 4 had a 20,21,22,23,24,25,26,27-octanordammarane triterpenoid skeleton [26]. In the HMBC spectra (Figure 2), the correlations of $\mathrm{H}-1, \mathrm{H}-5$ and $\mathrm{H}-28$ with one $\mathrm{C}=\mathrm{O}\left(\delta_{\mathrm{C}} 218.8\right)$ suggested that $\mathrm{C}-3$ was oxygenated and a ketone group. In the ${ }^{1} \mathrm{H},{ }^{1} \mathrm{H}-\mathrm{COSY}$ spectrum, signals for a spin system of $\mathrm{H}-9 / \mathrm{H}-11 / \mathrm{H}-12-\mathrm{O}-/$ $\mathrm{H}-13 / \mathrm{H}-17-\mathrm{O}-/ \mathrm{H}-16 / \mathrm{H}-15-\mathrm{O}$ were exhibited, indicating that C-12, C-15, and C-17 should be the three oxygenated $\mathrm{CH}$ at $\delta_{\mathrm{C}} 73.1,69.9$, and 76.4 respectively. The HMBC correlations of $\mathrm{H}-12\left(\delta_{\mathrm{H}} 4.47\right)$ with $\mathrm{C}=\mathrm{O}\left(\delta_{\mathrm{C}} 173.1\right)$ of acetyl group, and $\mathrm{H}-17\left(\delta_{\mathrm{H}} 3.98\right)$ with $\mathrm{OMe}\left(\delta_{\mathrm{C}} 58.6\right)$, indicated the location of $\mathrm{AcO}$, $\mathrm{MeO}$, and $\mathrm{OH}$ at $\mathrm{C}-12, \mathrm{C}-17$ and $\mathrm{C}-15$, respectively (Figure 2). In the ROESY spectrum, the correlations of $\mathrm{H}-12 / \mathrm{H}-30 / \mathrm{H}-17$, and of $\mathrm{H}-13 / \mathrm{H}-15$ indicated $\mathrm{AcO}$ and $\mathrm{MeO}$ were in a $\beta$-orientation, while the $\mathrm{OH}$ at $\mathrm{C}$-15 was in the $\alpha$-orientation. Therefore, the structure of 4 was elucidated as $12 \beta$-O-acetyl-15 $\alpha$-hydoxy17 $\beta$-methoxy-3-oxo-20,21,22-23,24,25,26,27-octanordammanrane.

Compound 5 was obtained as a white amorphous powder, and its molecular formula was deduced as $\mathrm{C}_{24} \mathrm{H}_{38} \mathrm{O}_{5}$ by HR-ESI-MS and ${ }^{13} \mathrm{C}$-NMR data analysis. The IR of 5 showed the strong absorption of ester $\left(1715 \mathrm{~cm}^{-1}\right)$, ketone $\left(1730 \mathrm{~cm}^{-1}\right)$, and hydroxyl $\left(3445 \mathrm{~cm}^{-1}\right)$. The ${ }^{1} \mathrm{H}$ - and ${ }^{13} \mathrm{C}-\mathrm{NMR}$ data of 5 and 4 were almost identical, indicating that $\mathbf{5}$ was also a derivative of 20,21,22,23,24,25,26,27-octanordammarane triterpenoid. Careful comparison of the NMR data of $\mathbf{5}$ with those of compound $\mathbf{4}$ showed that the only significant difference was that the singlet OMe signals in $\mathbf{4}$ was replaced by a $\mathrm{OH}$ group in compound $\mathbf{5}$, which was confirmed by the upfield chemical shift of C-17 from $\delta_{\mathrm{C}} 76.4$ to 71.5 . On the basis of the observation of similar NOESY data to those of $\mathbf{4}$, the stereochemistry of 5 was expected to be the same. Accordingly, the structure of 5 was established as $12 \beta$ - $O$-acetyl-15 $\alpha, 17 \beta$-dihydoxy-3-oxo-20,21,2223,24,25,26,27-octanordammanrane.

Compound 6 was obtained as a white amorphous solid. Its molecular formula was established by HR-ESI-MS as $\mathrm{C}_{22} \mathrm{H}_{34} \mathrm{O}_{3}$. Strong broad absorption at $3444 \mathrm{~cm}^{-1}$ and $1736 \mathrm{~cm}^{-1}$ in the IR spectrum of 6 indicated the presence of $\mathrm{OH}$ and $\mathrm{C}=\mathrm{O}$, respectively. Comparison the ${ }^{1} \mathrm{H}$ - and ${ }^{13} \mathrm{C}-\mathrm{NMR}$ of $\mathbf{6}$ with 5 
indicated that 6 had the similar skeleton of 20,21,22,23,24,25,26,27-octanordammarane triterpenoid. The most significant difference was that the signals of $\mathrm{CH}_{2}(\mathrm{C}-16)$ and oxygenated $\mathrm{CH}(\mathrm{C}-17)$ in 5 was replaced by two olefinic carbon signals $\left(\delta_{\mathrm{C}} 132.1\right.$ and 158.8) in 6, indicating that the hydroxyl group at $\mathrm{C}-17$ in 5 was eliminated to form the 16,17-ene in $\mathbf{6}$. These deductions were further confirmed by the observed HMBC and ${ }^{1} \mathrm{H}-{ }^{1} \mathrm{H}$ COSY correlations. On the basis of these evidences and the spectral data, the structure of compound $\mathbf{6}$ was determined as $12 \beta$-O-acetyl-15 $\alpha$-hydoxy-3-oxo-17-en-20,21,2223,24,25,26,27-octanordammanrane.

\subsection{Cytotoxic Activity}

All these compounds were evaluated for their in vitro cytotoxic potential against seven tumor cell lines by using the revised MTT method as described in the Experimental part. The results are summarized in Table 3. Octanordammarane triterpenoids 4-6 exhibited significant cytotoxicity against A-549 cells (lung cancer), BGC-823 cells (human gastric carcinoma), HepG2 cells (human hepatocellular carcinoma), HL-60 (human myeloid leukemia), MCF-7 cells (human breast cancer), SMMC-7721 (hepatocellular carcinoma), and W480 (colon cancer) with $\mathrm{IC}_{50}$ values of 12.3-17.1, 11.3-18.3, and 9.4-19.1, respectively. Trinordammarane triterpenoids 2 and 7 showed moderate cytotoxic activities against all assayed seven tumor cell lines $\left(20 \mu \mathrm{M}<\mathrm{IC}_{50} \leq 50 \mu \mathrm{M}\right)$. Hexanordammarane triterpenoids 3 and 8 possessed weak cytotoxic activities $\left(50 \mu \mathrm{M}<\mathrm{IC}_{50} \leq 80 \mu \mathrm{M}\right)$, while no cytotoxicity was exhibited for compound $1\left(\mathrm{IC}_{50} \geq 80 \mu \mathrm{M}\right)$. The nor-dammarane triterpenoids 1-8 isolated from $V$. mongolicum shared the same basic skeletal structure with a wide variety of side chains. Due to their intrinsic structural variety and impressive biological activities, we suggest the viewpoint that the introduction of appropriate side chains into a planar polycyclic pharmacophore might strengthen the cytotoxic action.

Table 3. Cytotoxicity of compounds $\mathbf{1}-\mathbf{8}$ against seven human tumor cell lines $\left(\mathrm{IC}_{50}, \mu \mathrm{M}\right)^{\mathrm{a}}$.

\begin{tabular}{clllllll}
\hline & Cell lines & & & & & & \\
\hline & A-549 & BGC-823 & HepG2 & HL-60 & MCF-7 & SMMC-7721 & W480 \\
$\mathbf{1}$ & 79.4 & 80.3 & 80.2 & 78.8 & 81.8 & 80.5 & 81.6 \\
$\mathbf{2}$ & 29.7 & 29.6 & 29.4 & 29.4 & 27.1 & 30.1 & 24.9 \\
$\mathbf{3}$ & 63.2 & 66.8 & 51.1 & 68.2 & 53.5 & 50.1 & 59.7 \\
$\mathbf{4}$ & 12.3 & 15.9 & 14.3 & 17.0 & 15.1 & 14.7 & 17.1 \\
$\mathbf{5}$ & 12.7 & 12.2 & 12.8 & 13.8 & 11.3 & 11.7 & 18.3 \\
$\mathbf{6}$ & 14.3 & 9.4 & 10.1 & 11.1 & 10.4 & 9.7 & 19.1 \\
$\mathbf{7}$ & 31.9 & 31.2 & 30.7 & 32.2 & 28.1 & 29.9 & 27.6 \\
$\mathbf{8}$ & 76.3 & 68.7 & 66.9 & 72.3 & 76.2 & 70.8 & 69.4 \\
Doxorubicin & 18.3 & 14.7 & 22.0 & 31.7 & 24.9 & 35.4 & 15.9 \\
\hline
\end{tabular}

${ }^{\mathrm{a}}$ Doxorubicin activities are expressed as $\mathrm{IC}_{50}$ values in $\mathrm{nM}$, and those of compounds $\mathbf{1}-\mathbf{8}$ are expressed as $\mathrm{IC}_{50}$ values in $\mu \mathrm{M}$. (-) $\mathrm{IC}_{50}>100 \mu \mathrm{M}$.

\subsection{Radical Scavenging Activity}

The compounds 1-8 were tested in vitro for their radical scavenging activities by both the DPPH and ABTS assays. The results (Table 4) showed that compounds 1-8 had no activities towards the tested 
DPPH radical. Comparing the $\mathrm{IC}_{50}$ values with that shown by Trolox in the two assays, compounds 4-6 seem to possess higher antiradical activities than other compounds on $\mathrm{ABTS}^{++}$radicals. The differences of antiradical activities of compounds 4-6 between DPPH and ABTS $^{++}$could be explained by the different mechanisms of the reactions for the two radicals, as has been reported for some compounds which possessed $\mathrm{ABTS}^{++}$scavenging activity, but did not exhibit DPPH scavenging activity [27].

Table 4. Free radical scavenging activity of compounds 1-8 evaluated with DPPH, ABTS ${ }^{++}$ assays $\left(\mathrm{IC}_{50}, \mu \mathrm{M}\right)$.

\begin{tabular}{cll}
\hline & DPPH $\mathbf{I C}_{\mathbf{5 0}}$ & $\mathbf{A B T S}^{+} \mathbf{I C}_{\mathbf{5 0}}$ \\
\hline $\mathbf{1}$ & $276.8 \pm 5$ & $309.1 \pm 6$ \\
$\mathbf{2}$ & $253.1 \pm 5$ & $241.0 \pm 5$ \\
$\mathbf{3}$ & $244.7 \pm 5$ & $256.1 \pm 5$ \\
$\mathbf{4}$ & $101.3 \pm 4$ & $68.1 \pm 4$ \\
$\mathbf{5}$ & $99.7 \pm 3$ & $59.2 \pm 3$ \\
$\mathbf{6}$ & $94.1 \pm 3$ & $54.6 \pm 3$ \\
$\mathbf{7}$ & $261.4 \pm 5$ & $299.1 \pm 5$ \\
$\mathbf{8}$ & $241.0 \pm 5$ & $271.3 \pm 6$ \\
Trolox & $42.8 \pm 1$ & $80.1 \pm 3$ \\
\hline
\end{tabular}

\section{Experimental}

\subsection{General}

Optical rotations were determined with a JASCO P2000 digital polarimeter (Tokyo, Japan). Ultraviolet (UV) and infrared (IR) spectra were obtained on JASCO V-650 and JASCO FT/IR-4100 spectrophotometers (Tokyo, Japan), respectively. NMR spectra were measured on a Bruker AM-600 spectrometer. EIMS and HREIMS $(70 \mathrm{eV})$ were carried out on a Finnigan MAT 95 mass spectrometer. All solvents used were of analytical grade (Shanghai Chemical Reagents Company Ltd., Shanghai, China). Silica gel (200-300 mesh), silica gel H (Qingdao Haiyang Chemical Co. Ltd., Qingdao, China), C18 reversed-phase silica gel (150-200 mesh, Merck), and MCI gel (CHP20P, 75-150 lm, Mitsubishi Chemical Industries Ltd., Tokyo, Japan) were used for column chromatography. HPLC separation was performed on an instrument consisting of a Waters 600 controller, a Waters 600 pump, and a Waters 2487 dual $\lambda$ absorbance detector, with a Prevail $(250 \times 10 \mathrm{~mm}$ i.d.) preparative column packed with C18 silica $(5 \mu \mathrm{m})$.

\subsection{Plant Material}

The whole plants of $V$. mongolicum were collected in Hanzhong Shanxi Province, China, in April 2010. The sample was identified by one of the authors (W. Wang). A specimen (VM201004001) was deposited in the Herbarium of Shengyang Medicine College, Shengyang, China.

\subsection{Extraction and Isolation}

The dried whole plants of $V$. mongolicum $(15 \mathrm{~kg}$ ) were powdered and extracted with $80 \% \mathrm{EtOH}$ $(20 \mathrm{~L} \times 3)$ at room temperature. After removal of $\mathrm{EtOH}$ under reduced pressure, the aqueous brownish 
syrup ( $1 \mathrm{~L})$ was suspended in $\mathrm{H}_{2} \mathrm{O}(1 \mathrm{~L})$ and then partitioned with chloroform $(1 \mathrm{~L} \times 3)$ to afford $137 \mathrm{~g}$ chloroform-soluble fractions. The chloroform-soluble fraction $(137 \mathrm{~g})$ was further fractionated through a silica gel column, eluted with $\mathrm{CHCl}_{3}-\mathrm{Me}_{2} \mathrm{CO}$ (from 1:0 to 0:1), to obtain eleven fractions (1-11) according to TLC analysis. Fraction 3 (2.3 g) was applied to an ODS MPLC column and eluted with $\mathrm{MeOH}-\mathrm{H}_{2} \mathrm{O}(20: 80,30: 70,40: 60$, each $500 \mathrm{~mL})$ to yield four subfractions (Fr. 3-1 and 3-4). Fr. 3-2 ( $\mathrm{MeOH}-\mathrm{H}_{2} \mathrm{O}, 413 \mathrm{mg}$ ) was chromatographed by a Sephadex LH-20 column eluted with $\mathrm{MeOH} / \mathrm{CHCl}_{3}$ (50:50), and purifed by a preparative RP-HPLC (ODS column, $250 \times 20 \mathrm{~mm}$ ) using $\mathrm{MeOH} / \mathrm{H}_{2} \mathrm{O}(25: 75)$ as mobile phase to afford $3(77 \mathrm{mg})$ and $7(63 \mathrm{mg})$. Fr. 3-3 $\left(\mathrm{MeOH}-\mathrm{H}_{2} \mathrm{O}, 215 \mathrm{mg}\right)$ was purified by a preparative RP-HPLC (ODS column, $250 \times 20 \mathrm{~mm}$ ) using $\mathrm{MeOH} / \mathrm{H}_{2} \mathrm{O}$ (30:70) as mobile phase to obtain 4 (61 mg). Fraction 4 (1.5 g) was applied to an ODS MPLC column and eluted with $\mathrm{MeOH} / \mathrm{H}_{2} \mathrm{O}$ $(20: 80,30: 70,40: 60$, each $500 \mathrm{~mL}$ ) to yield two subfractions (Fr. 4-1 and Fr. 4-2). Subfraction 4-2 (317 mg) was purified by a preparative RP-HPLC (ODS column, $250 \times 20 \mathrm{~mm}$ ) using $\mathrm{MeOH} / \mathrm{H}_{2} \mathrm{O}$ (33:67) as mobile phase to obtain $2(61 \mathrm{mg})$ and $\mathbf{6}(67 \mathrm{mg})$. Separation of fraction 5 (4.2 g) by silica gel column chromatography, eluted with petroleum ether- $\mathrm{Me}_{2} \mathrm{CO}$ (from 8:1 to 1:1), afforded six subfractions (Fr. 5-1 and Fr. 5-6). Fr. 5-2 (278 mg) was subjected to RP-18 (MeOH- $\mathrm{H}_{2} \mathrm{O}$, from 2:8 to 6:4) and Sephadex LH-20 (MeOH) column chromatography to yield 1 (53 mg). Fr. 5-3 (203 mg) was repeatedly chromatographed on silica gel (chloroform:methanol, from 20:1 to 10:1) and then purifed by a Sephadex LH-20 column eluted with $\mathrm{MeOH} / \mathrm{H}_{2} \mathrm{O}$ (50:50) to afford 5 (67 mg) and 8 (78 mg).

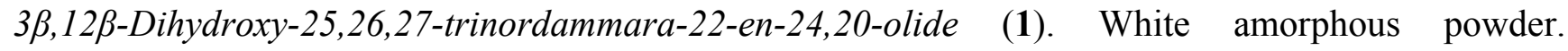
$[\alpha]_{D}^{23.3}=+0.4(c=0.40, \mathrm{MeOH}) . \mathrm{UV}\left(\mathrm{CDCl}_{3}\right) \lambda_{\max }(\log \varepsilon): 198(0.10) \mathrm{nm} . \mathrm{IR}(\mathrm{KBr}) v_{\max } 3450,2945$, 2870, 1702, 1640, 1605, 1463, 1384, 1247, $1107 \mathrm{~cm}^{-1} .{ }^{1} \mathrm{H}-\mathrm{NMR}\left(\mathrm{CDCl}_{3}, 600 \mathrm{MHz}\right)$ data see Table 1, ${ }^{13} \mathrm{C}-\mathrm{NMR}\left(\mathrm{CDCl}_{3}, 125 \mathrm{MHz}\right)$ data see Table 2. EI-MS $m / z: 430$ ([M] $\left.{ }^{+}\right)$. HR-ESI-MS (pos.) $m / z$ : $453.2984\left([\mathrm{M}+\mathrm{Na}]^{+}, \mathrm{C}_{27} \mathrm{H}_{42} \mathrm{O}_{4} \mathrm{Na}\right.$. calcd. 453.2981).

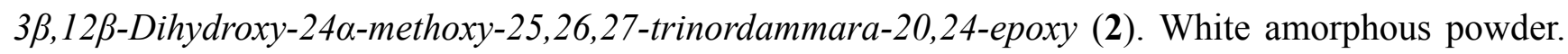
$[\alpha]_{D}^{23.3}=+27.1(c=0.11, \mathrm{MeOH}) . \mathrm{UV}\left(\mathrm{CDCl}_{3}\right) \lambda_{\max }(\log \varepsilon): 205(0.56) \mathrm{nm}$. IR (KBr) $v_{\max } 3425,2945$, 2876, 1630, 1383, 1276, $1033 \mathrm{~cm}^{-1} .{ }^{1} \mathrm{H}-\mathrm{NMR}\left(\mathrm{CDCl}_{3}, 600 \mathrm{MHz}\right)$ data see Table $1,{ }^{13} \mathrm{C}-\mathrm{NMR}\left(\mathrm{CDCl}_{3}\right.$, $125 \mathrm{MHz}$ ) data see Table 2. EI-MS $m / z: 448\left([\mathrm{M}]^{+}\right)$. HR-ESI-MS (pos.) $m / z: 471.3454\left([\mathrm{M}+\mathrm{Na}]^{+}\right.$, $\mathrm{C}_{28} \mathrm{H}_{48} \mathrm{O}_{4} \mathrm{Na}$. calcd. 471.3450).

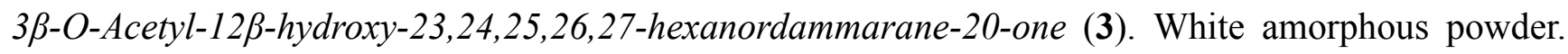
$[\alpha]_{D}^{23.3}=+46.3(c=0.15, \mathrm{MeOH}) . \mathrm{UV}\left(\mathrm{CDCl}_{3}\right) \lambda_{\max }(\log \varepsilon): 200(0.72) \mathrm{nm}$. IR (KBr) $v_{\max } 3440,2968$, 2945, 2870, 1705, 1463, 1384, 1365, 1177, 1042, $1007 \mathrm{~cm}^{-1} .{ }^{1} \mathrm{H}-\mathrm{NMR}\left(\mathrm{CDCl}_{3}, 600 \mathrm{MHz}\right)$ data see Table 1, ${ }^{13} \mathrm{C}-\mathrm{NMR}\left(\mathrm{CDCl}_{3}, 125 \mathrm{MHz}\right)$ data see Table 2. EI-MS m/z: $418\left([\mathrm{M}]^{+}\right)$. HR-ESI-MS (pos.) $m / z: 441.2978\left([\mathrm{M}+\mathrm{Na}]^{+}, \mathrm{C}_{26} \mathrm{H}_{42} \mathrm{O}_{4} \mathrm{Na}\right.$. calcd. 441.2981).

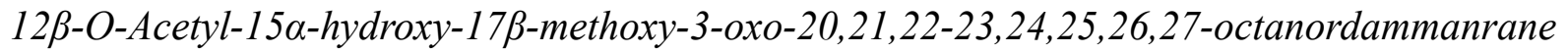

White amorphous powder. $[\alpha]_{D}^{23.3}=+15.4(c=1.210, \mathrm{MeOH})$. UV $\left(\mathrm{CDCl}_{3}\right) \lambda_{\max }(\log \varepsilon): 206(0.66) \mathrm{nm}$. IR (KBr) $v_{\max } 3450,1735,1635,1345 \mathrm{~cm}^{-1} .{ }^{1} \mathrm{H}-\mathrm{NMR}\left(\mathrm{CDCl}_{3}, 600 \mathrm{MHz}\right)$ data see Table $1,{ }^{13} \mathrm{C}-\mathrm{NMR}$ $\left(\mathrm{CDCl}_{3}, 125 \mathrm{MHz}\right)$ data see Table 2. EI-MS m/z: $420\left([\mathrm{M}]^{+}\right)$. HR-ESI-MS (pos.) $\mathrm{m} / z$ : 443.2774 $\left([\mathrm{M}+\mathrm{Na}]^{+}, \mathrm{C}_{25} \mathrm{H}_{40} \mathrm{O}_{5} \mathrm{Na}\right.$. calcd. 443.2773). 


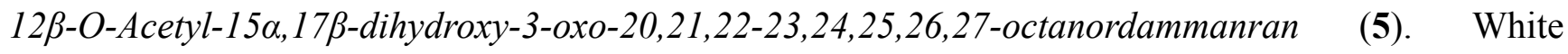
amorphous powder. $[\alpha]_{D}^{23.3}=+11.4(c=1.130, \mathrm{MeOH})$. UV $\left(\mathrm{CDCl}_{3}\right) \lambda_{\max }(\log \varepsilon): 205(0.69) \mathrm{nm}$. IR $(\mathrm{KBr}) v_{\max } 3445,1730,1715,1625,1034 \mathrm{~cm}^{-1} .{ }^{1} \mathrm{H}-\mathrm{NMR}\left(\mathrm{CDCl}_{3}, 600 \mathrm{MHz}\right)$ data see Table 1, ${ }^{13} \mathrm{C}-\mathrm{NMR}\left(\mathrm{CDCl}_{3}, 125 \mathrm{MHz}\right)$ data see Table 2. EI-MS m/z: $406\left([\mathrm{M}]^{+}\right)$. HR-ESI-MS (pos.) $\mathrm{m} / z$ : calcd. 429.2613 ([M+Na $]^{+}, \mathrm{C}_{24} \mathrm{H}_{38} \mathrm{O}_{5} \mathrm{Na}$. calcd. 429.2617).

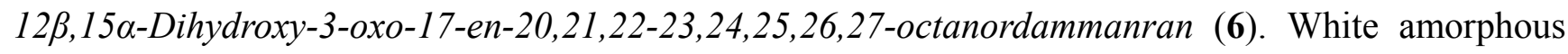
powder. $[\alpha]_{D}^{23.3}=+10.7(c=0.460, \mathrm{MeOH})$. UV $\left(\mathrm{CDCl}_{3}\right) \lambda_{\max }(\log \varepsilon): 202(0.54) \mathrm{nm}$. IR $(\mathrm{KBr}) v_{\max }$ 3444, 1736, 1630, $1034 \mathrm{~cm}^{-1} .{ }^{1} \mathrm{H}-\mathrm{NMR}\left(\mathrm{CDCl}_{3}, 600 \mathrm{MHz}\right)$ data see Table $1,{ }^{13} \mathrm{C}-\mathrm{NMR}\left(\mathrm{CDCl}_{3}, 125 \mathrm{MHz}\right)$ data see Table 2. EI-MS m/z: $346\left([\mathrm{M}]^{+}\right)$. HR-ESI-MS (pos.) $m / z: 369.2405\left([\mathrm{M}+\mathrm{Na}]^{+}, \mathrm{C}_{22} \mathrm{H}_{34} \mathrm{O}_{3} \mathrm{Na}\right.$. calcd. 369.2406).

\subsection{Cytotoxicity Assay in Vitro}

The isolated compounds 1-8 were subjected to cytotoxic evaluation against A-549 cells (lung cancer), BGC-823 cells (human gastric carcinoma), HepG2 cells (human hepatocellular carcinoma), HL-60 (human myeloid leukemia), MCF-7 cells (human breast cancer), SMMC-7721 (hepatocellular carcinoma), and W480 (colon cancer) by employing the revised MTT method as described in the literature [28,29]. Doxorubicin was used as the positive control. All tumor cell lines were cultured on RPMI-1640 medium supplemented with $10 \%$ fetal bovine serum, $100 \mathrm{U} \mathrm{mL}^{-1}$ penicillin and $100 \mu \mathrm{g} / \mathrm{mL}$ streptomycin in $25 \mathrm{~cm}^{2}$ culture flasks at $37{ }^{\circ} \mathrm{C}$ in humidified atmosphere with $5 \% \mathrm{CO}_{2}$. For the cytotoxicity tests, cells in exponential growth stage were harvested from culture by trypsin digestion and centrifuging at $180 \times g$ for $3 \mathrm{~min}$, then resuspended in fresh medium at a cell density of $5 \times 10^{4}$ cells per mL. The cell suspension was dispensed into a 96 -well microplate at $100 \mu \mathrm{L}$ per well, and incubated in humidified atmosphere with $5 \% \mathrm{CO}_{2}$ at $37^{\circ} \mathrm{C}$ for $24 \mathrm{~h}$, and then treated with the compounds at various concentrations $(0,1,10,100 \mu \mathrm{M})$. After $48 \mathrm{~h}$ of treatment, $50 \mu \mathrm{L}$ of $1 \mathrm{mg} / \mathrm{mL}$ MTT solution was added to each well, and further incubated for $4 \mathrm{~h}$. The cells in each well were then solubilized with DMSO $(100 \mu \mathrm{L}$ for each well) and the optical density (OD) was recorded at $570 \mathrm{~nm}$. All drug doses were tested in triplicate and the $\mathrm{IC}_{50}$ values were derived from the mean $\mathrm{OD}$ values of the triplicate tests versus drug concentration curves. The $50 \%$ inhibition concentration $\left(\mathrm{IC}_{50}\right.$ value) was determined by curve fitting and was used as criteria to judge the cytotoxicity (active: $\mathrm{IC}_{50} \leq 20 \mu \mathrm{M}$; moderately active: $20 \mu \mathrm{M}<\mathrm{IC}_{50} \leq 80 \mu \mathrm{M}$; not active: $\mathrm{IC}_{50}>80 \mu \mathrm{M}$ ). All cell lines were purchased from Cell Bank of Shanghai Institute of Biochemistry \& Cell Biology, Chinese Academy of Sciences. Other reagents were purchased from Shanghai Sangon Biological Engineering Technology \& Services Co., Ltd. (Shanghai, China).

\subsection{Microplate Assay for Radical Scavenging Activity DPPH}

Microplate DPPH assay was performed as described by [30]. Briefly, in a 96-well plate, successively sample dilutions (standard stocks of different samples $5 \mathrm{mM}$ ), in triplicate, received DPPH solution (40 $\mu \mathrm{M}$ in methanol) in a total volume of $0.2 \mathrm{~mL}$ and absorbance was measured at $550 \mathrm{~nm}$ with a microplate reader. Results were determined each $5 \mathrm{~min}$ until $60 \mathrm{~min}$ in order to evaluate kinetic behavior of the reaction. The percentage of remaining DPPH was calculated as follows: 
$\% \mathrm{DPPH}_{\text {rem }}=100 \times\left([\mathrm{DPPH}]_{\text {sample }} /[\mathrm{DPPH}]_{\text {blank }}\right)$. A calibrated Trolox (6-hydroxy-2,5,7,8tetramethylchroman-2-carboxylic acid, $3.9 \mathrm{mM}$ initial concentration) standard curve was also made. The percentage of remaining DPPH against the standard concentration was then plotted in an exponential regression, to obtain the amount of antioxidant necessary to decrease the initial DPPH concentration by $50 \%\left(\mathrm{IC}_{50}\right)$.

\subsection{2,2'-Azino-bis(3-ethylbenzothiazoline-6-sulfonic acid) (ABTS) Radical Cation Decolorization Assay}

$\mathrm{ABTS}^{++}$radical scavenging activity was determined according to $\mathrm{Re}$ [31]. The $\mathrm{ABTS}^{++}$cation radical was produced by the reaction between $7 \mathrm{mM} \mathrm{ABTS}$ in $\mathrm{H}_{2} \mathrm{O}$ and $2.45 \mathrm{mM}$ potassium persulfate, stored in the dark at room temperature for $16 \mathrm{~h}$. Before usage, the $\mathrm{ABTS}^{-+}$solution was diluted with phosphate buffer (0.05 M, pH 7.4) to get an absorbance of $0.800 \pm 0.035$ at $734 \mathrm{~nm}$. The solution is stable for 2 days. Different concentrations of extracts or pure compounds in methanol solution were added to $1 \mathrm{~mL}$ of $\mathrm{ABTS}^{-+}$solution. The mixture was incubated at $37{ }^{\circ} \mathrm{C}$ in the dark. After $30 \mathrm{~min}$ of incubation, the percentage inhibition of absorbance at $734 \mathrm{~nm}$ was calculated for each concentration relative to a blank absorbance (methanol). All determinations were carried out at least three times, and in triplicate. The capability to scavenge the $\mathrm{ABTS}^{+}$radical was calculated using the following equation:

$$
\operatorname{ABTS}^{++} \text {scavenging effect }(\%)=100-\left[\left(\mathrm{A}_{\text {Sample }} / \mathrm{A}_{\text {Control }}\right) \times 100\right]
$$

where in $\mathrm{A}_{\text {Control }}$ is the initial concentration of the $\mathrm{ABTS}^{+}$and $\mathrm{A}_{\text {Sample }}$ is absorbance of the remaining concentration of $\mathrm{ABTS}^{+}$in the presence of different compounds. Trolox was used as reference. The stock concentrations of Trolox and of different compounds tested are the same as reported in DPPH assay.

\section{Conclusions}

A chemical investigation of the $80 \% \mathrm{EtOH}$ extract of the dried whole plants of $V$. mongolicum resulted in the isolation of six new nor-dammarane triterpenoids, 3 $\beta, 12 \beta$-dihydroxy-25,26,27trinordammara-22-en-24,20-olide (1), 3 $\beta, 12 \beta$-dihydroxy-24 $\alpha$-methoxy-25,26,27-trinordammara-20,24epoxy (2), 3 $\beta$-O-acetyl-12 $\beta$-hydroxy-23,24,25,26,27-hexanordammarane-20-one (3), 12 $\beta$-O-acetyl$15 \alpha$-hydroxy-17 $\beta$-methoxy-3-oxo-20,21,22-23,24,25,26,27-octanordammanrane $\quad(4), \quad 12 \beta$ - $O$-acetyl$15 \alpha, 17 \beta$-dihydroxy-3-oxo-20,21,22-23,24,25,26,27-octanordammanrane (5), and $12 \beta, 15 \alpha$-dihydroxy3-oxo-17-en-20,21,22-23,24,25,26,27-octanordammanrane (6), together with two known compounds, 12 $\beta$-hydroxy-3-oxo-24 $\alpha$-methoxy-25,26,27-trinordammara-20,24-epoxy (7) and $3 \beta, 12 \beta$-dihydroxy23,24,25,26,27-hexanordammarane-20-one (8). Previous studies have indicated that significant antioxidant property of some natural products might be responsible for their antitumor property [27], suggesting that a triterpenoid possessing both antioxidant and antiproliferative activities could offer a broad spectrum of bioactivities. In our present study, all the isolated compounds were evaluated in vitro for their cytotoxic activities against seven tumor cell lines and radical scavenging properties. Octanordammarane tertripenoids 4-6 showed particular cytotoxic activities against all tested tumor cell lines, with low $\mathrm{IC}_{50}$ values of less than $20 \mu \mathrm{M}$, and exhibited radical scavenging activities against $\mathrm{ABTS}^{+}$radicals with $\mathrm{IC}_{50}$ values comparable with that of the standard drug Trolox. 


\section{Acknowledgements}

We thank Lei Ling (Department of Pharmacy, No.202 Hospital of PLA) for bioassays of cytotoxic activities.

\section{References}

1. Lobstein, A.; Haan-Archipoff, G.; Englert, J.; Kuhry, J.G.; Anton, R. Chemotaxonomical investigation in the genus Viburnum. Phytochemistry 1999, 50, 1175-1180.

2. Jordheim, M.; Giske, N.H.; Andersen, Ø.M. Anthocyanins in Caprifoliaceae. Biochem. Syst. Ecol. 2007, 35, 153-159.

3. Kubo, M.; Chen, I.S.; Fukuyama, Y. Vibsane-type diterpenes from Taiwanese Viburnum odoratissimum. Chem. Pharm. Bull. 2001, 49, 242-245.

4. Lobstein, A.; Weniger, B.; Malécot, V.; Um, B.H.; Alzate, F.; Anton, R. Polyphenolic content of two Colombian Viburnum species (Caprifoliaceae). Biochem. Syst. Ecol. 2003, 31, 95-97.

5. Wang, L.Q.; Chen, Y.G.; Xu, J.J.; Liu, Y.; Li, X.M.; Zhao, Y. Compounds from Viburnum species and their biological activities. Chem. Biodivers. 2008, 5, 1879-1899.

6. Parveen, M.; Khan, M.S.; Shafiullah; Ilyas, M. Luteolin 3'-xylosyl $(1 \rightarrow 2)$ glucoside from viburnum grandifolium. Phytochemistry 1998, 49, 2535-2538.

7. Mohamed, M.A.; Marzouk, M.S.A.; Moharram, F.A.; El-Sayed, M.M.; Baiuomy, A.R. Phytochemical constituents and hepatoprotective activity of Viburnum tinus. Phytochemistry 2005, 66, 2780-2786.

8. Fukuyama, Y.; Minoshima, Y.; Kishimoto, Y.; Chen, I.S.; Takahashi, H.; Esumi, T. Iridoid glucosides and p-coumaroyl iridoids from Viburnum luzonicum and their cytotoxicity. J. Nat. Prod. 2004, 67, 1833-1838.

9. Fukuyama, Y.; Minoshima, Y.; Kishimoto, Y.; Chen, I.S.; Takahashi, H.; Esumi, T. Cytotoxic iridoid aldehydes from Taiwanese Viburnum luzonicum. Chem. Pharm. Bull. 2005, 53, 125-127.

10. Tomassini, L.; Brkic, D. Iridoid glucosides from Viburnum lantana var. discolor. Planta Med. 1997, 63, 485-486.

11. Fukuyama, Y.; Minami, H.; Ichikawa, R.; Takuchi, K. Hydroperoxylated guaiane-type sesquiterpenes from Viburnum awabuki. Phytochemistry 1996, 42, 741-746.

12. Fukuyama, Y.; Fujii, H.; Minami, H.; Takahashi, H.; Kubo, M. Neovibsanin F and its congeners, rearranged vibsane-type diterpenes from Viburnum suspensum. J. Nat. Prod. 2006, 69, 1098-1100.

13. Fukuyama, Y.; Kubo, M.; Minami, H.; Yuasa, H.; Matsuo, A.; Fujii, T.; Morisaki, M.; Harada, K. Rearranged vibsane-type diterpenes from Viburnum awabuki and photochemical reaction of vibsanin B. Chem. Pharm. Bull. 2005, 53, 72-80.

14. Fukuyama, Y.; Minami, H.; Kagawa, M.; Kodama, M.; Kawazu, K. Chemical conversion of vibsanin $\mathrm{C}$ to vibsanin $\mathrm{E}$ and structure of 3-hydroxyvibsanin $\mathrm{E}$ from viburnum awabuki. J. Nat. Prod. 1999, 62, 337-339.

15. Fukuyama, Y.; Minami, H.; Matsuo, A.; Kitamura, K.; Akizuki, M.; Kubo, M.; Kodama, M. Seven-membered vibsane-type diterpenes with a 5,10-cis relationship from Viburnum awabuki. Chem. Pharm. Bull. 2002, 50, 368-371. 
16. Shen, Y.C.; Lin, C.L.; Chien, S.C.; Khalil, A.T.; Ko, C.L.; Wang, C.H. Vibsane diterpenoids from the leaves and flowers of Viburnum odoratissimum. J. Nat. Prod. 2004, 67, 74-77.

17. El-Gamal, A.A.; Wang, S.K.; Duh, C.Y. New diterpenoids from Viburnum awabuki. J. Nat. Prod. 2004, 67, 333-336.

18. Shen, Y.C.; Prakash, C.V.; Wang, L.T.; Chien, C.T.; Hung, M.C. New vibsane diterpenes and lupane triterpenes from Viburnum odoratissimum. J. Nat. Prod. 2002, 65, 1052-1055.

19. Fukuyama, Y.; Minami, H.; Fujii, H.; Tajima, M. Triterpenoids from Viburnum suspensum. Phytochemistry 2002, 60, 765-768.

20. Kagawa, M.; Minami, H.; Nakahara, M.; Takahashi, H.; Takaoka, S.; Fukuyama, Y. Oleanane-type triterpenes from Viburnum awabuki. Phytochemistry 1998, 47, 1337-1341.

21. Rios, M.Y.; González-Morales, A.; Villarreal, M.L. Sterols, triterpenes and biflavonoids of Viburnum jucundum and cytotoxic activity of ursolic acid. Planta Med. 2001, 67, 683-684.

22. Kim, M.Y.; Iwai, K.; Onodera, A.; Matsue, H. Identification and antiradical properties of anthocyanins in fruits of Viburnum dilatatum thunb. J. Agric. Food Chem. 2003, 51, 6173-6137.

23. Zhu, X.D.; Dong, X.J.; Luo, S.D. Phenolic Compounds from Viburnum cylindricum. Helv. Chim. Acta 2005, 88, 339-342.

24. Machida, K.; Nakano, Y.; Kikuchi, M. Phenolic glycosides from Viburnum dilatatum. Phytochemistry 1991, 30, 2013-2014.

25. Tu, L.; Zhao, Y.; Yu, Z.Y.; Cong, Y.W.; Xu, G.; Peng, L.Y.; Zhang, P.T.; Cheng, X.; Zhao, Q.S. Six New Dammarane Triterpenoids from Viburnum cylindricum. Helv. Chim. Acta 2008, 91, 1578-1587.

26. Wang, F.; Guan, Y.J. Cytotoxic nor-dammarane triterpenoids from Dysoxylum hainanense. Fitoterapia 2012, 83, 13-17.

27. Tundis, R.; Bonesi, M.; Deguin, B.; Loizzo, M.R.; Menichini, F.; Conforti, F.; Menichini, F. Cytotoxic activity and inhibitory effect on nitric oxide production of triterpene saponins from the roots of Physospermum verticillatum (Waldst and Kit) (Apiaceae). Bioorg. Med. Chem. 2009, 17, $4542-4547$.

28. Jirapast, S.; Serm, S.; Pongpun, S.; Suttira, K.; Jonkolnee, J.A.; Santi, T.P. Two new cytotoxic isomeric indole alkaloids from the roots of Nauclea orientalis. Fitoterapia 2010, 81, 830-833.

29. Zhang, Y.; Wang, J.; Wei, D.; Wang, X.; Luo, J.; Kong, L. Cytotoxic tirucallane C26 triterpenoids from the stem barks of Aphanamixis grandifolia. Phytochemistry 2010, 71, 2199-2204.

30. Brem, B.; Seger, C.; Pacher, T.; Hartl, M.; Hadacek, F.; Hofer, O.; Vajrodaya, S.; Greger, H. Antioxidant dehydrotocopherols as a new chemical character of Stemona species. Phytochemistry 2004, 65, 2719-2729.

31. Re, R.; Pellegrini, N.; Proteggente, A.; Pannala, A.; Yang, M.; Rice-Evans, C. Antioxidant activity applying an improved ABTS radical cation decolorization assay. Free Radic. Biol. Med. 1999, 26, 1231-1237.

Sample Availability: Samples of the compounds 1-8 are available from the authors.

(C) 2013 by the authors; licensee MDPI, Basel, Switzerland. This article is an open access article distributed under the terms and conditions of the Creative Commons Attribution license (http://creativecommons.org/licenses/by/3.0/). 